\title{
ІНФОРМАЦЙНІ ТЕХНОЛОГІї
}

УДК: 811.93

д.т.н., проф. Лснков С.В. (ВІКНУ)

д.Т.н., с.н.с. Комарова Л.О. (ДУІТЗ)

к.пед.н. Дорошенко Т.В. (ДУІТЗ)

Солодєєва Л.В. (ВІКНУ)

DOI: https://doi.org/10.17721/2519-481X/2021/70-07

\section{АНАЛІЗ ПРОБЛЕМ ЛІНГВІСТИЧНОГО ЗАБЕЗПЕЧЕННЯ КІБЕРФІЗИЧНИХ СИСТЕМ НАНОТЕХНОЛОГІЙ}

Статтю присвячено аналізу перспектив взасмодії нанотехнології й прикладної лінгвістики у сфері функціонування інформації в автоматизованих наносистемах різних типів, зокрема використанню лексичних одиниць семантичного поля - «нанотехнології», обстеженню стану лексикографічних $і$ термінографічних джерел професійної мови в області нанотехнології $i$ наноіндустрії в загальній системі інформаційної безпеки держави.

Сучасна інформаційна безпека формується на мікро- $і$ нанорівнях, що сприяє знаходженню нових рішень з численними можяливостями цивільного і військового застосування. Авторки доводять, що розроблення сучасних нанотехнологічних засобів дозволяє отримати потенціал, щц може бути порівняний за фактором руйнівності з ударною міццю зброї масового ураження. Однією з найбільш жсахливих перспектив с поява нанороботів з елементами колективного розуму, що могли б використовувати навколиинє середовище для відтворення собі подібних машин. У цьому ракурсі створювані нанотехнології виступають як новий клас озброєнь. Отэсе, виникає нагальна необхідність дослідження всієї парадигми нанотехнологій задля з'ясування позитивних $i$ негативних наслібків ̈̈х використання, зокрема здійснення аналізу терміносистеми нанотехнологій $і$ наноматеріалів, дослідження механізмів ї̈ формування, виявлення основних особливостей термінів. Актуальним вважасться застосування прикладних можливостей лінгвістики за напрямками лінгвістичного забезпечення функціонування інформації в автоматизованих наносистемах різних типів. Саме лінгвістичне забезпечення (визначення мови представлення $i$ управління інформацією) $\epsilon$ сполучною ланкою між «природним» та інформаційним середовищем.

Ключові слова: нанотехнологія, прикладна лінгвістика, наноіндустрія, лінгвокібернетика, мововедення, когнітивна лінгвістика, безпека держави, кіберфізичні системи

Вступ та постановка проблеми. Науково-технічна революція (далі - НТР) другої половини $\mathrm{XX}$ століття сприяла якісному реформуванням продуктивних сил на основі перетворення науки на провідний чинник розвитку громадського виробництва. НТР виникла під впливом наукових і технічних відкриттів XX століття та зумовила високі вимоги до рівня освіти, кваліфікації, культури, організованості й відповідальності працівників. Кінець ХX століття означений початком Третьої науково-технічної революції, пов'язаної з виникненням нанотехнології. Перші ідеї щодо можливого використання нанотехнології з'явилися ще в сімдесяті роки минулого століття в Японії і США. Так, у 1974 році на конференції Японського суспільства точного машинобудування Норіо Танігучи запропонував метод оброблення матеріалів із надвисокою (нанометровою) точністю [1]. На початку 1980-х років у книзі «Машини творення: прийдешня ера нанотехнології» К. Е. Дрекслер обгрунтував потенціал молекулярних машин i можливості контролю над синтезом складних речовин як нанотехнології - «очікуваної технології виробництва, орієнтованої на дешеве отримання пристроїв і речовин із заздалегідь заданою атомарною структурою» [2]. Наукові дослідження цієї проблеми вчений представив через рік у праці «Наносистеми» [3]. де обгрунтував зв'язок наномашин із законами фізики, хімії, і квантової механіки, запропонувавши використовувати для створення атомних пристроїв вуглець, а як допоміжні елементи - водень, азот, кисень, арсенід, фосфор, кремній і германій. А через п'ять років у книзі «Механізми створення» [4] 
описав фізичні принципи систем молекулярного виробництва нанотехнології, що можуть оперувати окремими атомами.

У 30-х рр. ХХ століття була виявлена структура атома, з'ясовано, що він складається 3 ядра, навколо якого обертаються з великою швидкістю електрони, що несуть електрику; в результаті з'явилася новітня фізична теорія - квантова фізика. Це була революція в історії розвитку фізики, вона поглибила уявлення вчених про матеріальний світ. Раніше дослідження велися на рівні речовини, пізніше - на рівні атома, після відкриття структури атома і створення квантової фізики, вони перейшли на рівень елементарних частинок. Це революційний розвиток фізичної теорії значно підвищив здатність людства використовувати і перетворювати матеріальний світ. Найяскравіший вираз наукової революції XX століття, атомні винаходи, [5] що стали результатом появу нових технологій та відповідно - нової науки. Але найголовніше - змінили геополітичне обличчя світу, де фундаментальні дисципліни сконцентрувалися навколо таких дисциплін, як нанофізика, нанохімія, нанобіологія, наногеноміка, теоретична наномедицина, наногеологія, наноелектроніка, квантова інформатика тощо [6].

Термін «нанотехнологія» обєднав два поняття - «нано» і «технологія». Префікс «нано» у назві фундаментальних дисциплін означає, що всі вони досліджують світ матеріальних структур і процесів, співмасштабних із нанометром, тобто з однією мільярдною часткою метра. Поняття «технологія» (грецьк. techne - мистецтво, майстерність, уміння + logos наука) означає сукупність методів обробки, виготовлення, зміни стану (властивостей, форми) первинної сировини в процесі виробництва кінцевої продукції [6].

Нанотехнологія дозволяє здійснювати маніпуляції з речовиною на рівні 3 точністю 1 нанометр (I нм $=10^{-9}$ м, одна мільярдна частина метра), що означає можливість керування процесами в атомарному й молекулярному масштабі. На цьому рівні розмірів зникають межі не лише між звичними основними напрямами науки (фізика, хімія, біологія), але навіть і між ïx прикладними або суміжними розділами (типу матеріалознавства, механіки, електроніки, генетики й нейробіології) [7,8].

Метою дослідження $є$ обгрунтування напрямів інтегрування лінгвістичного знання у сфері нанотехнології, аналіз перспектив взаємодії нанотехнології й прикладної лінгвістики у сфері функціонування інформації в автоматизованих наносистемах різних типів, зокрема використанню лексичних одиниць семантичного поля - «нанотехнології», обстеженню стану лексикографічних і термінографічних джерел професійної мови в області нанотехнології і наноіндустрії в загальній системі інформаційної безпеки держави.

Аналіз останніх досліджень. У даний час термін «нанотехнологія» має низку дефініцій: «Нанотехнологія - дослідження і технологічні розробки на атомному, молекулярному чи макромолекулярному рівнях у шкалі розмірів приблизно від 1 до 100 нм, що проводяться для одержання фундаментальних знань про природу явищ та властивостей матеріалів у наношкалі, а також для створення і використання структур, приладів і систем, що набувають нових якостей завдяки своїм маленьким розмірам. Нанотехнологічні дослідження та розробки включають контрольовані маніпуляції нанорозмірними структурами та їхню інтеграцію в більш великі компоненти, системи й архітектури» [3].

«Нанотехнологія - сукупність наукових знань, способів і засобів спрямованого регульованого складання (синтезу) з окремих атомів і молекул різних речовин, матеріалів та виробів із лінійним розміром елементів структури до $100 \mathrm{Hм}\left(1 \mathrm{Hм}=10^{-9} \mathrm{M} ; 1 \mathrm{Hм}=10 \AA\right)$ » [8] та інші. Але справедливо відзначити що, для системного розвитку всієї інфраструктури наноіндустрії необхідно перш за все впорядкування термінології. Необхідно визначити напрями взаємодії між нанотехнологією і лінгвістикою і в першу чергу, лексичні одиниці семантичного поля - "нанотехнології".

Швидкий розвиток нанонауки і нанотехнологій, на думку більшості експертів, визначає зміст чергового (після інформаційно-технологічного і біотехнологічного) етапу науковотехнічної революції рис. 1. 


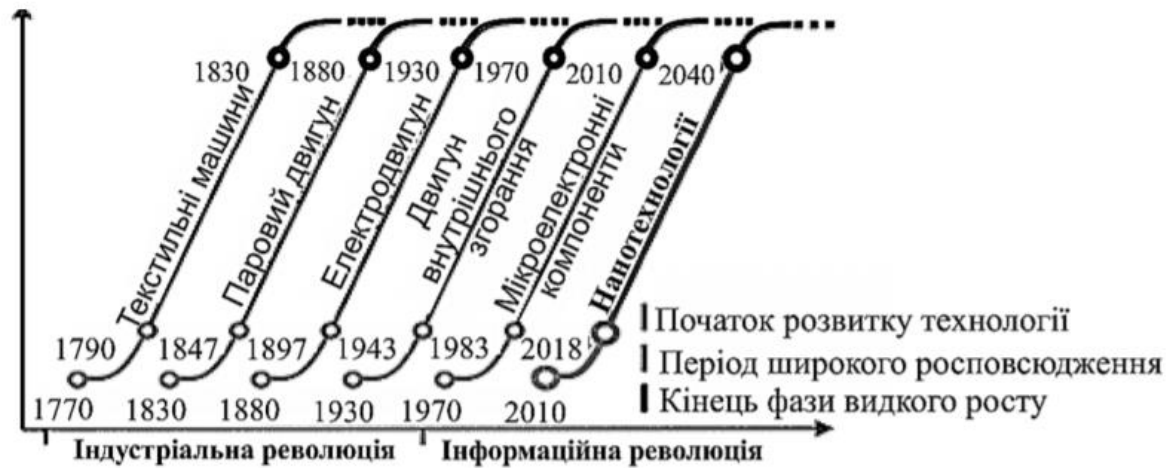

Рисунок 1 - Зміна технологічних укладів і поколінь техніки

Результати, до яких можуть призвести розвиток і поширення нанотехнологій, видаються вельми радикальними за своїми наслідками і глобальними за масштабами. Причому це стосується не тільки і навіть не стільки (в силу спірність наявних прогнозів) віддалених ефектів, але насамперед найближчих, вже початківців проявлятися наслідків для зміни науково-технологічних потенціалів країн i їх глобальної конкурентоспроможності. Нанотехнологічна революція це реальність (рис. 2).

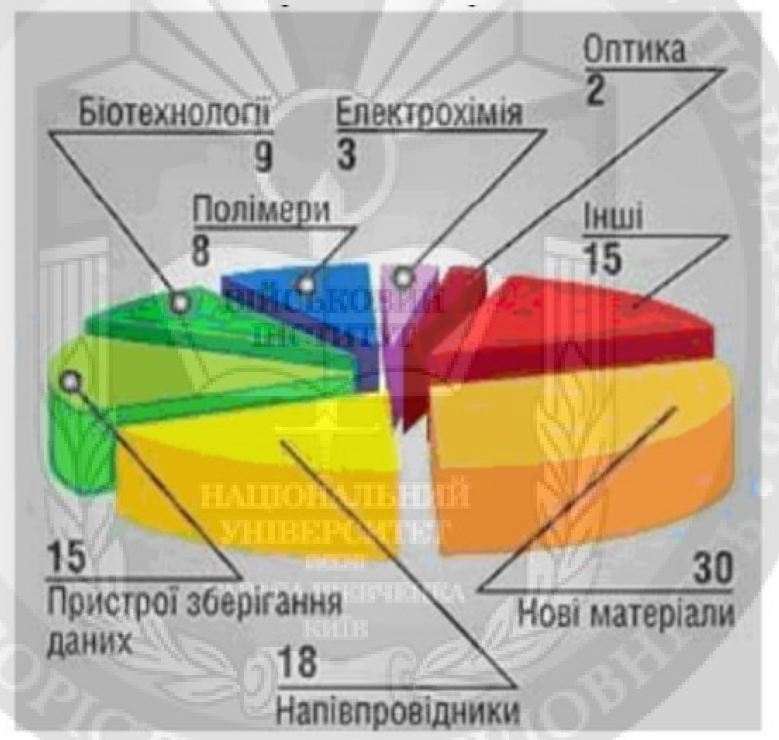

Рисунок 2 - Сфери використання нанотехнологій

Четверта промислова революція стала новим напрямом розвитку: проведена інтеграція фізичних і матеріальних світів з віртуальними інформаційними технологіями. В результаті чого з'являються нові типи систем - кіберфізичні системи [9]. Якщо раніше фахівці 3 інформаційної безпеки мали справу з захистом комп'ютерних систем, до яких можна віднести і мобільні пристрої, то тепер до них додалися ще фізичні пристрої, які принесли нові проблеми забезпечення інформаційної безпеки. I інтеграція даного типу систем в критично важливі галузі: атомну енергетику, хімічну промисловість, охорону здоров'я, потребує вирішення питання забезпечення кібербезпеки.

Виклад основного матеріалу. Сьогоднішні наукові пошуки здійснюються на межі наук, маргінальні дослідження призводять до найвірогідніших результатів. Ця міждисциплінарність й забезпечує схожість дослідницьких підходів у сфері нанотехнологій та суміжних лінгвістичних наук (наприклад, лінгвопрагматики, лінгвокогнітології, психолінгвістики, математичної лінгвістики тощо), що реалізується за такими параметрами:

1. Міждисциплінарний підхід до наукових пошуків, зумовленість методів дослідження системним підходом. 
2. Інтеграція знань і дослідницьких підходів.

3. Залучення до наукових пошуків фахівців різних наукових галузей. Наприклад, нанотехнологія об'єднує фахівців і дослідників в області фізики, хімії, медицини, біології, математики, соціології, тощо.

4. Нанотехнологія, подібно до лінгвістики, передбачає проблемно-, а не наочноорієнтовані дослідження. І нанотехнологія, і лінгвістика пов'язані із процесами моделювання, але для різних цілей. Провідним принципом нанотехнології є самовідтворювання аналогічного механізму іншого масштабу. Лінгвістика розглядає питання моделі різних комунікативних одиниць - від слова до дискурсу.

На порядку денному - забезпечення лінгвістичного супроводу наноіндустрії. Взаємодія фахівців цих наукових галузей може здійснюватися за різними напрямками, зокрема нагальним питанням $\epsilon$ термінологічне забезпечення нанотехнології та наноіндустрії. Вирішити це питання можливо за умови створення:

-термінологічної бази даних нанотехнології та наноіндустрії;

- оформлення метамови цих напрямів;

-тлумачного науково-технічного словника з контекстним супроводом кількома мовами;

- різних типів електронних словників: одномовних тлумачних словників і тезаурусів, двомовних і багатомовних перекладних галузевих словників;

- системи автоматизованого перекладу (з різним ступенем автоматизованості);

- навчальних програм, орієнтованих на розвинення у здобувачів освіти іншомовних вербальних компетенцій в області професійної комунікації за напрямом «Нанотехнології, наноіндустрія».

Усі ці кроки допоможуть уникнути різного тлумачення термінів у процесі роботи над нанопроектами, а також забезпечать підгрунтя лінгвістичної освіти й професійної комунікації майбутніх фахівців у сфері наноіндустрії.

Означеними заходами взаємодія між нанотехнологією і лінгвістикою не вичерпується [9]. Згідно прогнозам, «саме розвиток нанотехнологій визначає зовнішність XXI століття, подібно до того як відкриття атомної енергії, винахід лазера і транзистора визначили зовнішність XX сторіччя» [3]. Як відзначають експерти [10], нанотехнології призведуть до революції у сфері маніпулюванні матерією, так само, як це зробили комп'ютери у сфері інформації.

Наприклад, сьогодні актуальності набуває питання щодо управління зондовим мікроскопом, що дозволяє спостерігати за нанооб'єктами і пересувати їх. У 1985 році в США був отриманий патент щодо можливого перенесення атомів із вістря зонду СТМ на зразок. Атомно-силова мікроскопія (АСM) була розроблена Г. Биннігом і Г. Рорером, яким за ці дослідження в 1986 році була присуджена Нобелівська премія [11,12]. Створення атомносилового мікроскопа, здатного відчувати сили тяжіння і відштовхування, що виникають між окремими атомами, дало можливість, нарешті, «побачити» нанооб'єкти й «доторкнутися» до них. Управління мікроскопом можливо за умови мовного супроводу, що безпосередньо пов'язане з розробкою автоматизованих систем розпізнавання і розуміння мови. Наприклад, у Франції вже були пущені в експлуатацію мікроскопи, керовані голосом, коли команди мікроскопу давав комп'ютер, запрограмований на голос хірурга, який проводить операцію [13].

Комп’ютеризація інформаційної сфери стимулювала розвиток нової сфери прикладної лінгвістики - комп'ютерної, що передбачає лінгвістичне забезпечення функціонування інформації в автоматизованих системах різних типів.

Підвищення ефективності мовного інтерфейсу взаємодії 3 автоматизованими пристроями можливо за умови збільшення пропускної спроможності при введенні даних у пристрій під час виконання завдань, коли очі і руки оператора зайняті, у спеціальному середовищі (наприклад, за наявності радіаційного випромінювання). 
Сучасні системи розпізнавання мови (у тому числі й військового призначення) включають різні мовні рівні, кожен 3 яких несе своє функціональне навантаження: акустичний, параметричний, лексичний, синтаксичний, семантичний і прагматичний[9].

Розпізнавання мови, засноване на аналізі акустичного сигналу, вимагає докладної акустичної характеристики сигналу. Ідентифікація конкретних слів потребує виділення всередині узагальнених класів додаткових фонетичних підкласів, так що в остаточному вигляді ієрархія фонетичних класів має форму бінарного дерева рішень. Виходячи з наявної узагальненої класифікації, пропонується процедура побудови оптимального дерева рішень.

Лінгвістичний процесор здійснює діалогову взаємодію з користувачем (експертом) на природній для нього мові (природна мова, професійна мова, мова графіки, тощо).

Призначення компонентів взаємодії полягає в наступному:

по-перше, організувати діалог користувач - експертна система, тобто розподілити функції учасників спілкування в ході кооперативного рішення завдання;

по-друге, обробити окреме повідомлення з урахуванням поточного стану діалогу, тобто здійснити перетворення повідомлення із природомовної форми у форму внутрішнього уявлення.

Функціонування автоматизованої системи потребує низки найсучасніших лінгвотехнологічних знань:

- про процес рішення задачі, тобто знання, що використовує при управлінні інтерпретатор;

- про мову спілкування і спосіб організації діалогу, використовувані лінгвістичним процесором;

- про спосіб уявлення і модифікації знань, використовувані компонентою придбання знань;

- щодо управління, використовувані пояснювальною компонентою (структурні знання). чинниками:

Вимоги до мовного супроводу нанотехнологічного процесу зумовлені такими

- завданнями нанотехнологічного процесу, визначеними способами і методами рішення;

-вимогами до мови спілкування і організації діалогу;

- обмеженнями щодо кількості результатів і способів їх отримання;

- ступенем спільності/конкретності знань про проблемну область, що доступна користувачеві.

Таким чином, лінгвокібернетика як наука про загальні закони отримання, зберігання, передачі і перетворення лінгвістичної інформації в складних керованих системах, охоплює не тільки технічні, але також і будь-які біологічні і соціальні системи.

Лінгвокібернетичні системи майбутнього, що призначені для виконання широкого класу функцій управління і реалізовуються за допомогою електронно-обчислювальної машини, мають низку особливостей, що можуть бути співвіднесені з властивостями систем управління, що $є$ притаманними живим організмам.

Існуючі сьогодні пристрої багато в чому поступаються людині, хоча й починають перебирати деякі функції інтелекту людини. Сучасними електронно-обчислювальними машинами (EОM) може сприйматися і перероблятися різна інформація (числова, символьна), у тому числі й інформація, необхідна для створення образів навколишнього світу.

У зв'язку з цим особливого значення набуває галузь кібернетики - мововедення, яка пов'язана 3 мовою, розвиток якої активізується просунутим рівнем нових інформаційних технологій.

При конструюванні нанокомп'ютерів вирішуються завдання, що передбачать розподіл функцій нейронів у процесі мислення, а, отже, і мовних операцій. Використання лінгвістичних підходів до вирішення цієї проблеми сприятиме розвитку когнітивної лінгвістики як інтегральної науки про когнітивні процеси у свідомості людини, що забезпечують оперативне 
мислення та пізнання світу та когнітивні механізми та структури людської свідомості досліджує через мовні явища [13].

Розвинення й впровадження в практику нанотехнології може забезпечити прогрес в усіх сферах життєдіяльності людини. Можна з упевненістю стверджувати, що в цьому столітті нанотехнологія стане стратегічним напрямом розвитку науки i техніки, що зажадає фундаментальної перебудови існуючих технологій виробництва промислових виробів, лікарських препаратів, систем озброєння й тощо, а також зумовить глибокі перетворення в організації систем енергопостачання, охороні довкілля, транспорті, зв'язку, обчислювальній техніці [13].

Розроблення нанокомп'ютерів передбачає міждисциплінраний підхід, зокрема інтегрування таких напрямів:

- біоінформатики;

- нейроінформатики;

- розпізнавання слухових і зорових образів;

- когнітивної психології;

- штучного інтелекту;

- нейрофізіології;

- нейролінгвістики;

- лінгвокібернетики.

Таке інтегрування зумовлено тим, що «в рамках біоінформаційного наукового напряму передбачається розроблення й розвинення біоінформаційних технологій для виробництва біокомп'ютерних антропоморфних засобів» [14]. Такі біокомп'ютери (суміщені з організмом людини штучні засоби) здатні, наприклад, до навчання, можуть бути створені на основі складних молекулярних структур і наноструктур із реалізацією навчання по алгоритмах навчання штучних нейтронних мереж.

Біоінформаційні знання дозволять розробити і створити принципово нові засоби, що забезпечують, наприклад, ефективний розвиток і функціонування когнітивною, рефлексією, $\mathrm{i}$ інших, зокрема, можливо нових систем людини[15].

Даний підхід, природно, включає облік лінгвокогнітивного механізму отримання, зберігання, перероблення й передавання мовних образів у процесі мововідтворення i мовосприймання вербальної інформації.

Таким чином, принципове значення для розвинення підходів щодо створення нанокомп'ютерів має розроблення моделі функціонування нейтронних мереж на рівні мововідтворення і мовосприймання, а так і кодування-декодування семантичної інформації [14].

Тому можна стверджувати, що взаємодія між нанотехнологіями і лінгвістикою реальна, перспективна і вимагає глибокого розуміння як з боку фахівців у галузі нанотехнології, так і 3 боку фахівців у галузі фундаментальної і прикладної лінгвістики.

Висновки. Перспективи взаємодії нанотехнології і лінгвістики зараз можуть бути сформульовані за такими напрямами:

1) розроблення лінгвістичного забезпечення інформаційного поля в області нанотехнологій;

2) створення автоматизованих систем управління за допомогою голосу і мови стосовно нанороботів-наноманіпуляторів;

3) формування лінгвокогнітивного механізму, що забезпечує високу ефективність функціонування нанокомп'ютерів.

Сьогодні світ входить в новий етап розвитку інформаційних і комунікаційних технологій, що визначатиме економічне зростання і сталий розвиток світу в наступні десятиліття. У майбутньому люди, системи і об'єкти будуть взаємодіяти безперешкодно один 3 одним в сценаріях інтернету речей. Мовний супровід цих процесів набуватиме все більшої актуальності, що зумовить розквіт прикладної лінгвістики та ії інтегрування у сферу нанотехнологій. 


\section{ЛІТЕРАТУРА:}

1. Uskoković, V. I. Entering the era of nanoscience: time to be so small. Nanotechnol. N 9. 2013. p.p. $1441-1470$.

2. Drexler, K.E. Molecular nanomachines: physical principles and implementation strategies .Annu. Rev. Biophys. Biomol. Struct. 1994. P.377-405.

3. . Drexler, K.E. Enginesofcreation. The Coming Era of Nanotechnology. NewYork, Anchor Books Double-day. 1986.P. 299.

4. Taniguchi, N. On the Basic Concept of «Nano-Technology».Tokyo. Japan Society of Precision Engineering, 1974.

5. Ehrlich, G. Small objects - big ideas. A broad look at nanotechnology Moscow. Binom. 2011. P.254.

6. Ratner, M., Ratner. D. Nanotechnology: A Gentle Introduction to the Next Big Idea. Moscow. Williams. 2006.C. 240.

7. Movchan, B.A. Electron beam hybrid nanotechnology for deposition of inorganic materials in vacuum. Actual problems of modern materials science. Kiev, Akademperiodika, 2008, P.227-247.

8. Poole, C., Owens, F. Nanotechnology. Moscow. Technosphere. 2006. P.336

9. Heltier, H., Zippl W., Ronyan, D., Volkers, G. Molecular Modeling: Theory and Practice. Molecular Modeling: Basic Principles and Applications. Moscow. Binom. 2012.P. 319.

10. Whitesides, D., Eigler, D.,. Anders, R. Nanotechnology in the next decade: forecasting the direction of research. Moscow. Peace. 2002.C. 291.Харченко, В.К. Лингвосенсорика: Фундаментальные и прикладные аспекты. Москва. Книжный дом «Либроком». 2012.P.216

11. Dovgy, SO Nobel Prize winners 1901-2001: encyclopedic reference book. Kiev.Ukr. publishing center. 2001. P.768

12. Chekman, IS Nobel family. Kiev. NPV "Cooperative". 2007. P. 152

13. Chernytska, TV Current trends in the world market of nanotechnology in the global environment. Bulletin of Chernihiv State Technological University. Series. Economic sciences. Vip. 1 2013.C154-158.

14. Zelenin, VV On the other side of the truth: neurolinguistic programming as a weapon of information and propaganda war: a textbook. Kyiv, Fierce case. 2015.P. 384.

\section{REFERENCES:}

1. Uskoković, V. I. Entering the era of nanoscience: time to be so small. Nanotechnol. N 9. 2013. p.p. $1441-1470$

2. Drexler, K.E. Molecular nanomachines: physical principles and implementation strategies .Annu. Rev. Biophys. Biomol. Struct. 1994. P.377-405.

3. Drexler, K.E. Enginesofcreation. The Coming Era of Nanotechnology. NewYork, Anchor Books Double-day. 1986.P. 299.

4. Taniguchi, N. On the Basic Concept of «Nano-Technology».Tokyo. Japan Society of Precision Engineering, 1974.

5. Ehrlich, G. Small objects - big ideas. A broad look at nanotechnology Moscow. Binom. 2011. P.254.

6. Ratner, M., Ratner. D. Nanotechnology: A Gentle Introduction to the Next Big Idea. Moscow. Williams. 2006.C. 240.

7. Movchan, B.A. Electron beam hybrid nanotechnology for deposition of inorganic materials in vacuum. Actual problems of modern materials science. Kiev, Akademperiodika, 2008, P.227-247.

8. Poole, C., Owens, F. Nanotechnology. Moscow. Technosphere. 2006. P.336

9. Heltier, H., Zippl W., Ronyan, D., Volkers, G. Molecular Modeling: Theory and Practice. Molecular Modeling: Basic Principles and Applications. Moscow. Binom. 2012.P. 319.

10. Whitesides, D., Eigler, D.,. Anders, R. Nanotechnology in the next decade: forecasting the direction of research. Moscow. Peace. 2002.C. 291.Харченко, В.К. Лингвосенсорика: Фундаментальные и прикладные аспекты. Москва. Книжный дом «Либроком». 2012.P.216

11. Dovgy, SO Nobel Prize winners 1901-2001: encyclopedic reference book. Kiev.Ukr. publishing center. 2001. P.768

12. Chekman, IS Nobel family. Kiev. NPV "Cooperative". 2007. P. 152

13. Chernytska, TV Current trends in the world market of nanotechnology in the global environment. Bulletin of Chernihiv State Technological University. Series. Economic sciences. Vip. 1 2013.C154-158.

14. Zelenin, VV On the other side of the truth: neurolinguistic programming as a weapon of information and propaganda war: a textbook. Kyiv, Fierce case. 2015.P. 384. 


\section{Prof. Komarova L.O., Prof. Lienkov C.V., Ph.D. Doroshenko T.V., Solodeeva L.V. ANALYSIS OF THE PROBLEMS OF LINGUISTIC SUPPORT OF CYBERPHYSICAL SYSTEMS OF NANOTECHNOLOGIES}

The article deals with analyses of prospects for relationship between nanotechnology and applied linguistics in the field of information functioning in automated nanosystems of various types, including the use of lexical units of the semantic field - nanotechnology; to review the state of lexicographic and terminological sources of professional language in the field of nanotechnology and nanotechnology industry in the general system of information security of the state.

Modern information security is formed at the micro- and nano-levels, which contributes to finding new solutions with numerous possibilities of civil and military application. The authors prove that the development of modern nanotechnological devices allows to obtain a potential that can be comparable with the factor of ruinability of the mass destruction weapon. One of the most frightening prospects is the emergence of nanorobots with elements of collective intelligence, which could use the natural environment for the creation of similar machines. From this perspective, the nanotechnologies being created are a new class of armaments. Therefore, there is a general need to investigate the whole paradigm of nanotechnology in order to identify positive and negative effects of their use, In particular, the analysis of nanotechnology and nanomaterials therminosystems, examination of the mechanisms of their formation, and identification of the main features of the terms. The use of applied possibilities of linguistics for linguistic support of information functioning in automated nanosystems of various types is considered actual. The linguistic support (determining the language of representation and information management) is a spliced link between the "natural" and the information environment.

Keywords: nanotechnology, applied linguistics, nanoindustry, linguocybernetics, behavioral science, cognitive linguistics, state security, cybernetic systems. 